\title{
ペニシリンよりデスアセトキシセファロス ポリンおよび新しい誘導体への転換
}

\author{
Convevsion of Penicillins into Desacetoxycephalosporins \\ and Modified $\beta$-Lactamttantibiotics
}

紙 谷

孝*

Tkashi KAMIYA*

\section{I. はじめに}

ペニシリン（以下 Pc）は最初に実用化された抗生物 質であり, 古くから細菌感染症の治療に使われてきた。 この発見以来三十年にわたり化学的および微生物学的興 味から広範な研究が行なわれ，約十数種におよぶ半合成 Pc が実用化され今日の隆盛を見るに至っている。

一方セファスポリン (以下 $\mathrm{Cp}$ ) が単離)され，1961 年その構造が決定 ${ }^{2}$ されて以来, 世界的な注目をあび, Pc と同様広範な研究が進められてきた。技術上の困難 さから，1960年代後半に漸く実用化されるに至った。今 日数種の半合成 $\mathrm{Cp}$ が市販されているが, Pc 耐性菌お よびグラム陰性菌に有効などの特徴によって広く使用さ れ, 広域性抗生物質の一つとして重要な位置を占めつつ ある。

近年抗生物質の変換ないしは化学的修飾が重要な研究 対象となっているが,これら $\beta$-ラクタム抗生物質におけ る最近の注目すべき傾向は， Pc より $\mathrm{Cp}$ および新しい $\beta$-ラクタム抗生物質 (modified $\beta$-lactam antibiotics) 化学的に変換しようとする研究である。それは Pc が工 業的にしかも安価に生産されて有用な原料であること, および不安定でしかも活性に必要な $\beta$-ラクタム環の利 用が可能となったからである。Morin らの Pc からデス アセトキシ $\mathrm{Cp}$ への転換を端緒としてぼう大かつ多岐に わたる研究が報告され実用上ばかりでなく，有機化学的 飞も重要な成果が上りつつある。径口 $\mathrm{Cp}$ 剂, Cephalexin が3）Pc より工業的に生産され大きな成果を上げている

\section{* 藤沢薬品工業(株)中央研究所}

* Research Laboratories, Fujisawa Pharmaceutical Co., Ltd.

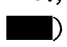

が，また同時に Cp 鼡ないしは新しい $\beta$-ラクタム抗生 物質に対する興味と期待がこの傾向を助長しているとい えよう。さらに最近 7-methoxy-Cp ${ }^{4}$ ) 功醴酵生産物より 新たに発見されて, これら $\beta$-ラクタム抗生物質の化学 的変換ないしは修飾に対する関心が高まりますます発展 しつつある。

これら最近の研究動向, 特に Pc からデスアセトオキ シ $\mathrm{Cp}$ への変換および modified $\beta$-lactam antibiotics への変換について著者らの研究を含め紹介してみたい。 $\mathrm{Pc}$ および $\mathrm{Cp}$ の化学, また抗菌活性などについては優 れた総説らがあるので割愛する。

\section{Pc よりデスアセトキシ $\mathrm{Cp}$ への転換}

1. Pc-sulfoxide の転換 1963 年 Morin $ら^{6)}$ は Pc-oxide (1) からデスアセトオキシ $\mathrm{Cp}$ (4) への転換 に始めて成功した。以来十余年にわたり多くの研究が行 なわれ，転移機構の解明さらに派生した新たな展開へと 今日の発展につながる重要な反応である。特に不安定な ß-ラクタム環を損障することなく, Pc の thiazolin 環を 開環した最初の例として意義が深い。まゔ発展の基礎と なった Morin らの方法から述べる。

Morin ら ${ }^{6)}$ は $\mathrm{Cp}$ が Pc より酸化段階が高いことに 着目し, Pc oxide (1) を無酢と加熱還流することにより penam (2) および cepham (3) の混合物を $2: 1$ の割合 で得た。（3） は塩基によって cephem（4）となり，(5a) の還元体 ${ }^{7)}$ と同定された。この結果始めて Pc と Cp と が化学的に関連づけられたことになるが, 最近 desacetoxy-Cp (5b) が醴酵生産物より単離8)されたので, 直接 Pc から転換に成功したともいえよう。(4) は（1）を少 量のトルエンスルホン酸とキシレン中加熱しても直接得 られるがその収率は 10〜15\% に過ぎない。その後基本 
<smiles></smiles>

(1)<smiles>CC(C)O</smiles>

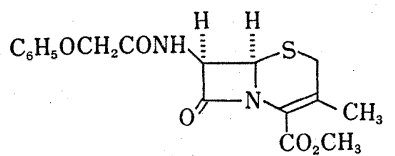

(4)<smiles>CCCCCCCCC</smiles><smiles>[X]CC1=C(C([R20])=O)N2C(=O)[C@H](NC([R])=O)[C@H]2SC1</smiles>

(5)

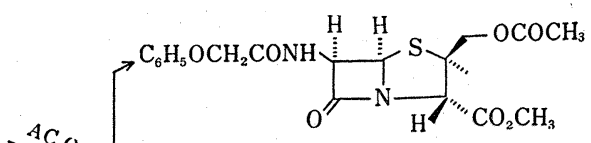

(2)

$+$

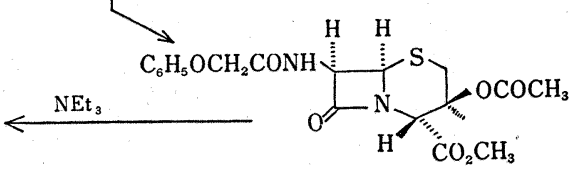

(3)

a) $\mathrm{R}=\mathrm{C}_{6} \mathrm{H}_{5} \mathrm{OCH}_{2} ; \mathrm{R}_{1}=\mathrm{CH}_{3} ; \mathrm{X}=\mathrm{OCOCH}_{3}$

b) $\mathrm{R}=\mathrm{HO}_{2} \mathrm{CCH}\left(\mathrm{CH}_{2}\right)_{8} ; \mathrm{X}=\mathrm{H}$ $\mathrm{N}_{2}$

反応として詳細な検討が行なわれ溶媒あるいは触媒が改 良された結果，DMF-無酢9)，ジオキサンーリン酸誘導体 ピリジン塩 ${ }^{10)}$ などを用いることにより，その収率は 70 〜80\% にまで達している。 cephalexin はこれらの方法 によって生産されているといわれている。

Morin らはこの反応機構を次の如く，(1) から無酢に よって sulfenic anhydride (6) を生じ, 次いで分子内の 二重結合に付加して生じた episulfonium ion (7) より （2）抢よび（3）を生成すると推定した。

この機構から（6）の生成前に sulfenic acid（9）の生

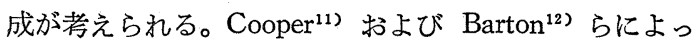
てほとんど同時にその存在が示された。すなわち Pc(s)oxide (8) ないしは (R)-oxide (10) を $\mathrm{D}_{2} \mathrm{O}$ または $t$ $\mathrm{BuOD}$ の存在下に加熱すると $\beta$-メチル基が $\mathrm{D}$ 化された (s)-oxide (11) を生成する。この事実は (8) および (10)

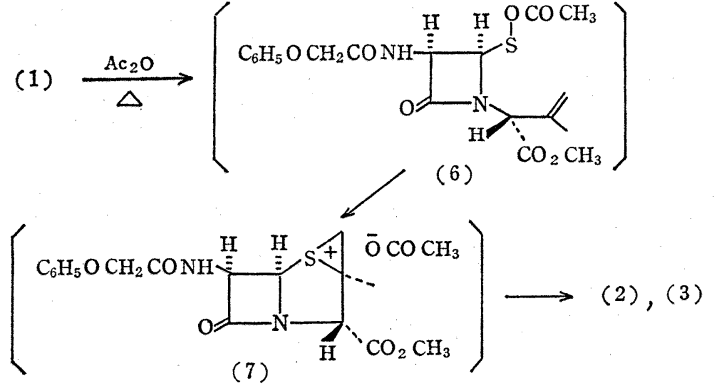

から同一の中間体 (9) を生じ D 交換後安定な (s)-oxide （11）に再閉環したものと理解される。(12a) でも同様 であるがこの場合は安定な $(\mathrm{R})$-oxide $(12 \mathrm{~b})^{13}{ }^{13}$ が得られ る。これら Pc-oxide と sulfenic acid との相互変換は oxide と cis の関係にあるメチル基が $6 \sigma$ の電子遷移状 態を経て sulfenic acid（9）となり再閉環することが明

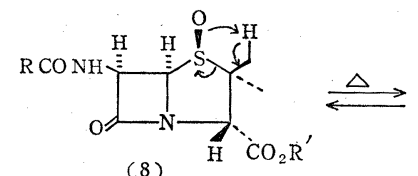

(8)

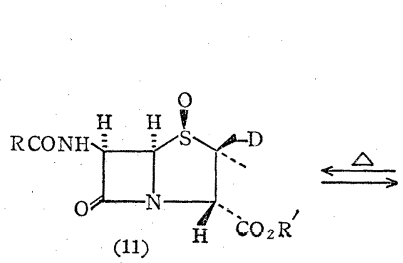

$\mathrm{R}=\mathrm{C}_{6} \mathrm{H}_{5} \mathrm{OCH}_{2} ; \quad \mathrm{R}^{1}=\mathrm{CCl}_{3} \mathrm{CH}_{2}$

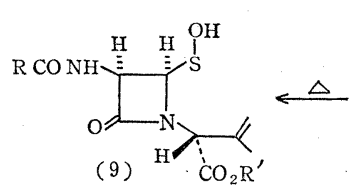

$\mathrm{D}_{2} \mathrm{O} \downarrow \uparrow \mathrm{H}_{2} \mathrm{O}$

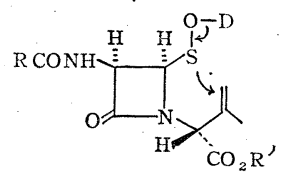

$\mathrm{CO}_{2} \mathrm{R}^{\prime}$

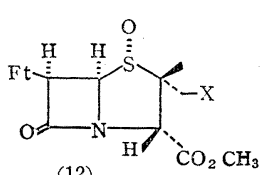

Ft=phthalimido a) $X=H$; b) $X=D$

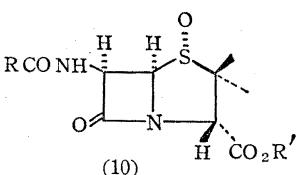

(10)

(12) 


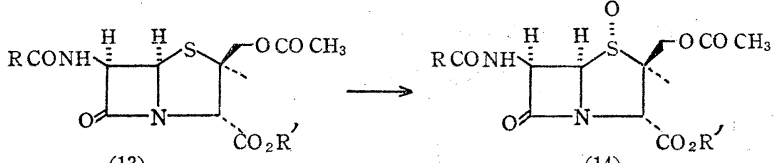

(13)

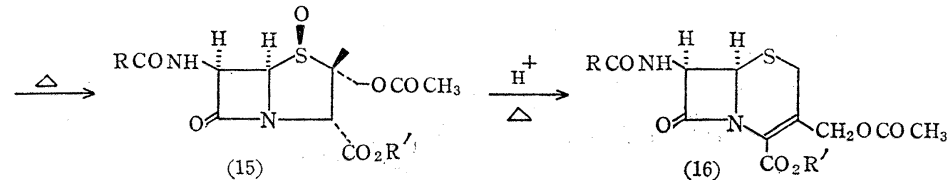

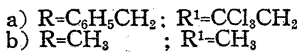

図 5

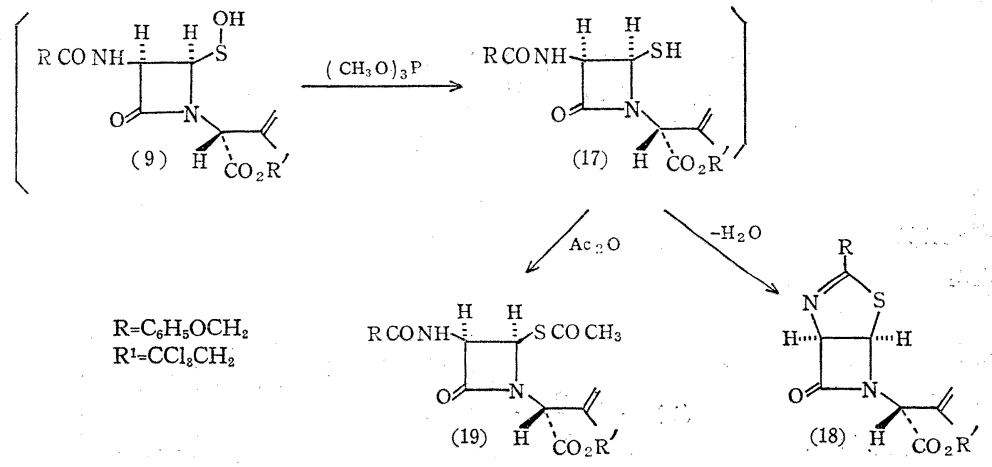

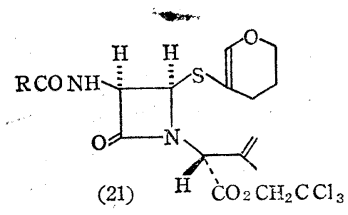

$\mathrm{R}=\mathrm{C}_{6} \mathrm{H}_{5} \mathrm{CH}_{2}$

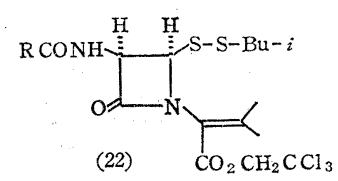

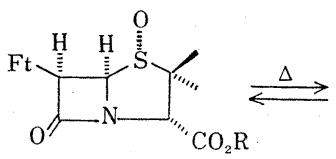

(23)

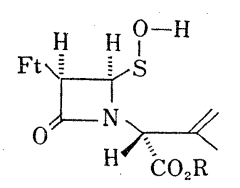

$\mathrm{H}^{\left.+{ }^{+} 4\right)} \backslash \mathrm{SO}_{2} \mathrm{Cl}_{2}$

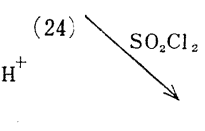

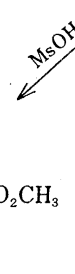

(27)

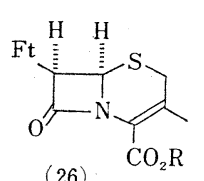

(26)

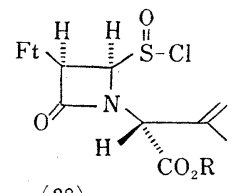

(28)

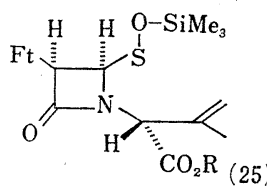

a) $\mathrm{R}=\mathrm{P}-\mathrm{NO}_{2}-\mathrm{C}_{6} \mathrm{H}_{4} \mathrm{CH}_{2}$ ，b) $\mathrm{R}=\mathrm{CH}_{3}$

らかとなった。

この結果を利用すれば Pc の望む メチル基に $\mathrm{AcO}$ 基を導入できる。 Barton $^{14)}$ らは $2 \beta$-acetoxy Pc (13) を水性ピリジン中 jodobenzene dichloride で酸化し (R)-oxide (14) した後, トルエン中加熱して（s）oxide（15a）に転換させることに成 功した。一方 Spry ${ }^{15)}$ は同様にして 得た（15b）を酸性条件下加熱して $\mathrm{Cp}$ (16) への転換に成功したが収率 は低いと報告している。 sulfenic acid (9) の存在が推定さ れるにおよび，その捕捉証明が行な われた。この最初の例は Cooperら ${ }^{16)}$ による還元的捕捉である。Pc-oxide (8) を $\left(\mathrm{CH}_{3} \mathrm{O}\right)_{3} \mathrm{P}$ と加熱すれば還 元して生成した thiol (17) が分子 内閉環し thiazolidine (18) が得ら れ，また無酢が存在すれば acetyl (19）が得られた。一方 Barton ら は反応性の高いオレブィンによる捕 捉を行ない，norbornadiene 打よび dihydropyran との反応により，そ れぞれ（20）拈よび（21）を得た。 また $i$-BuSH との反応により disulfide (22) ${ }^{18)}$ を得ているが，著者ら ${ }^{199}$ も全く別個に同種の反応を行なって いるので後述する。

最近 Chou ら ${ }^{20)}$ にって sulfenic acid (24) が単離証明された。すな わち Pc-oxide (23a) を酶酸エチル 中十分間加熱還流すれば（23a）之 sulfenic acid (24a) の混合物が $4: 1$ の割合で生成する。この混合物より 塩化メチレーンシクロヘキサンより 再結晶し（24a）を 10\% の収率で 単離することに成功した。(24) は silyl ester (25) ${ }^{21)}$ のメタノール分解 によっても得られる。この不安定と 考えられた sulfenic acid (24) の単 離は単に Pc-oxide 転換の中間体と しての存在が確定したばかりでな く, また同時に (24) からの発展が 期待されるものとしてきわめて重要 


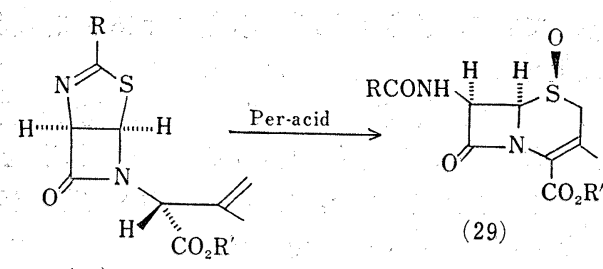

(18)
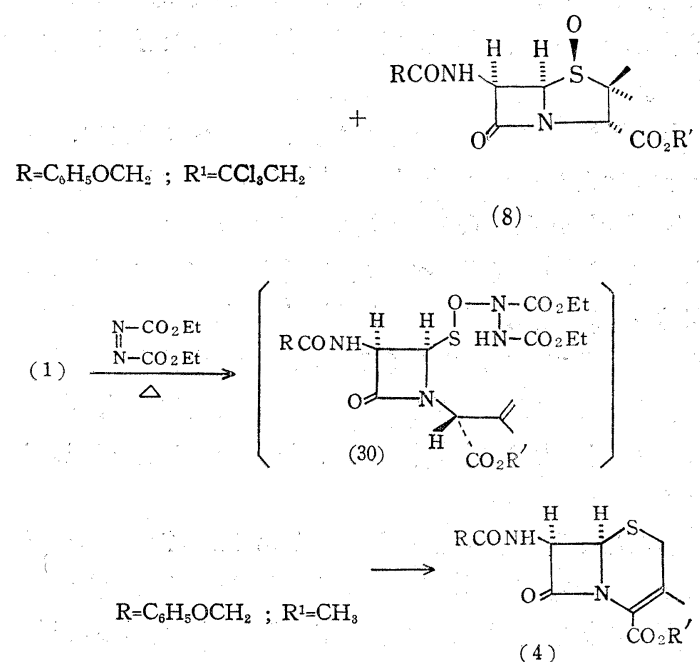

(4)

な結果である。(24) はベンゼンージメチルアセトアミド 中 $\mathrm{CH}_{3} \mathrm{SO}_{3} \mathrm{H}$ で処理すれば cephem $(26)^{22)}$ が，また塩 化メチレン中 $\mathrm{SO}_{2} \mathrm{Cl}_{2}$ によってクロル化すれば sulfinyl chloride (28) 23) をほとんど定量的に，また $\mathrm{CH}_{3} \mathrm{SO}_{3} \mathrm{H}$ と処理すれば高収率で（27）が得られるなど，それぞれ
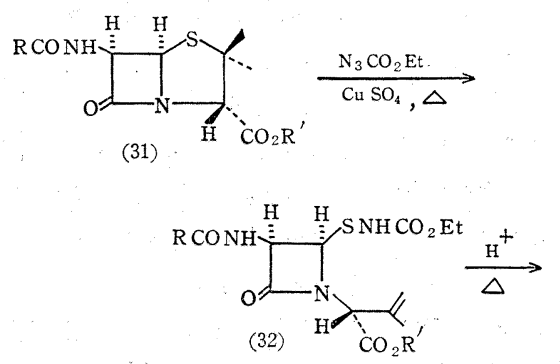

(23)

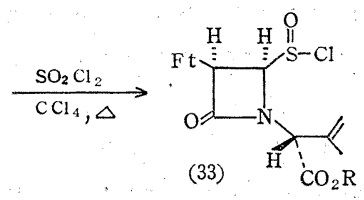

$\mathrm{R}=\mathrm{P}-\mathrm{NO}_{2} \mathrm{C}_{6} \mathrm{H}_{4} \mathrm{CH}_{2} ; \mathrm{CH}_{3}$

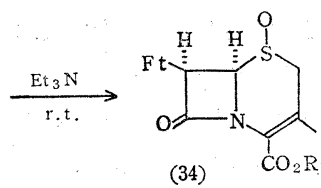

既存の結果に一致しその構造が確認された。

この結果, Pc-oxideの 環拡大機構は次のごとく説明 できる。すなわち，まづ熱シグマ転移によって sulfenic acid を生成し酸性条件下でプロトン化あるいは混合酸無 水物を形成する。次いで分子内二重結合との $\mathrm{SN}_{2}$, 反応 によって episulfonium ion を生じ, 以下最初に述べた ごとき生成物が得られる。一方 Cooper ら ${ }^{24)}$ はの分子 内二重結合との $\mathrm{SN}_{2}$ 反応の際に, 生成物の立体配位が a) $\mathrm{R}=\mathrm{C}_{6} \mathrm{H}_{5} \mathrm{CH}_{2}, \quad \mathrm{R}^{1}=\mathrm{CCl}_{3} \mathrm{CH}_{2}$

(8) $\stackrel{\mathrm{R}-\mathrm{SH}}{\longrightarrow}$

b) $\mathrm{R}=\mathrm{C}_{6} \mathrm{H}_{5} \mathrm{OCH}_{2}, \mathrm{R}^{1}=\mathrm{H}$

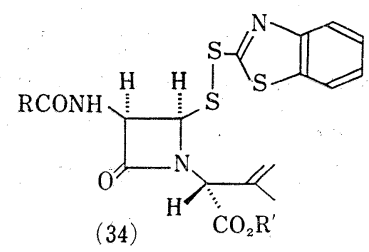

(34)

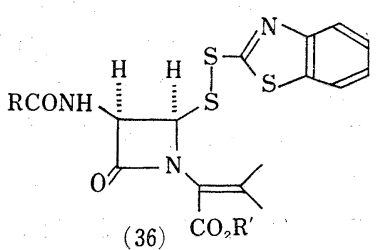

(36)

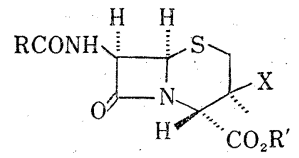

(37) $\mathrm{O}_{2} \mathrm{R}^{\prime}$

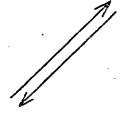

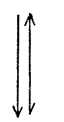

(35)

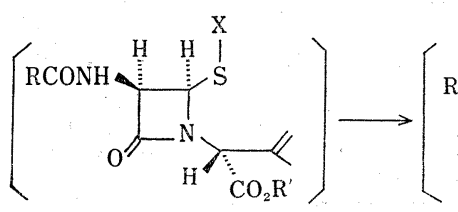

(38)

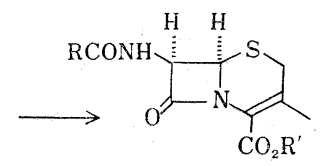

(40) 
決まるものとして立体化学的に説明している。

\section{2. その他の方法 以上の如く, Morin らの Pc-} oxide の転移に始まり上に述べたような発展をみたが， この間新しい環払大反応が検討された。漸く十年を経て 新しい報告がで始めつつある。以下それらについて簡単 に述べるが、いづれも Pc-oxide 転移反応と直接ないし は間接的に関係するといえよう。

Cooper ら ${ }^{25}$ は先の (18) を三フッ化䤀酸の存在下過 酸により酸化的に開環し, cephem-oxide (29) を得るこ とに成功したが收率は良好でない。この反応では (8)な ぞ数種の生成物が得られ反応中間体として sulfenic acid （9）の存在が考えられている。

Terao ら ${ }^{26)}$ は (1) をジオキサン中 diethyl azodicarbozylate と加熱することにより 26\% の収率で cephem （26）を得た。中間体として（30）を経ると推定している。 またジメチルアセトアミド中 $\alpha, \alpha$-azobis (N-methylformamide）を用いれば，その収率は 30〜 40\% に向上 すると報告している。

Numata ら ${ }^{26)}$ は Pc (31) より転換を試み二段階を経て cephem (4) を得ることに成功した。(31) を硫酸銅の存 在下 ethyl diazoformate と $90 \sim 100^{\circ}$ に加熱して sulfenamide (32) を $12 \%$ の収率で得た。この機構は Pc-oxide に相当する sulfilimine を経て進行すると考兄られてい る。（32）は $\mathrm{Et}_{3} \mathrm{~N}-\mathrm{HCl}$ と加熱し（4）得たが収率は低い と報告している。

Kukolja ${ }^{23)}$ は Pc-oxide (23) から cephem-oxide (34) への転換に成功した。(23) 四塩化炭素中 $\mathrm{SO}_{2} \mathrm{Cl}_{2}$ 加 熱して chloride（33）を定量的に得た。(33) は $\mathrm{S}$ 原子 にもとずく二種の異性体の混合物であるが分離はできな い。これを塩基で処理すればほとんど定量的に cephemoxide (34) に閉環する。

著者ら ${ }^{19)}$ も Pc-oxideの環拡大を検討し高収率で desacetoxy $\mathrm{Cp}$ への転換に成功した。後述する如く単に環拡 大反応だけを目的としたものでなく，新しい誘導体の合 成にも活用できるので詳しく述べたい。

前述の如く, Barton らは disulfide (22) ${ }^{18)}$ を合成し ているが，著者らも全く別個に Pc-oxide（8）と 2mercaptobenzothiazole などの heterocyclic thiol との反 応を検討し， disulfide（34）を 90\% 以上の収率で得た。 この (34)の特徴は先述のスルフエン酸捕捉体 (20), (22) などと異なり，S-S 結合を切断し再閉環できる点にあ る。(34) を塩化メチレン中泠却下 $1 / 2$ モルのハロゲン を作用させればほとんど定量的に halomethyl Pc (35) が得られるが，二重結合が共役した（36）では，同条件 下で全く原料を回収し二重結合の位置が重要であること
を示している。(35) は比較的不安定であって溶液とし て放置するか, やや温めれば定量的に安定な cepham （37）に転移する。(35) および（37）を塩基で処理すれ ば，(35）からは環の拡大を伴って cephem (40) を高収 率で得ることに成功した。この反応はや〉工程数が長い が，Pc-oxide から高收率で cephem (40) に誘導できる こと, および，ここに得た（34）および（35）は後述す る新しい誘導体合成の重要な中間体であるなどの特徴が ある。

disulfide (34) から halomethyl (35) への機構は, 八 ロゲンによりまづ sulfenic halide (38) を生じ, 次いで episulfonium ion (39) を経ているものと考えられる。 また（35）加ら（37）への転移，(35）打よび (37) から (40) への機構も同じく episulfonium ion (39) を経由 すると考えている。また (35)の halomethyl 基は NOE の測定によって $\beta$ 配位であることが判明したが，(37） の $\mathrm{Br}$ 基もその転移機構より $\beta$ 配位であると推定して いる。

ところで先に述べた episulfonium ion (7) は八ログ ンイオンが存在するならば, episulfonium ion (39) と の間が平衡を生ずると考えられる。したがって Pc-oxide （8）より直接（35）ないしは（37）が得られるものと期 待された。(8) をピリジンーピリジン塩酸塩とテトラク ロルエタン中で加熱することにより, cephem (40) とと もに（35a）を 15\% の収率で得ることに成功した。同様 に谷田ら ${ }^{28)}$ は (8) と酸クロリドーピリジンにより，また 小山ら ${ }^{29)}$ は塩化スズと加熱することにより（35a）を得た と報告している。また Kukolja ら ${ }^{27)}$ は Pc-oxide (23) を塩基の存在下塩化チオニールと加熱することにより, （35）および（37）に相当する chloride を得たと報告し ているが，(37) が（35）の転移によって生じたが，ある いは直接得られたかについては言及していない。

\section{Modified $\beta$-Lactam Antibiotics への変換}

Pc-oxide の転移によって示されたように, $\beta$-ラクタ ム環を損障することなく thiazoline 環の開環が可能とな った。この結果を利用して, 活性に必要な $\beta$-ラクタム 環を修飾し新しい誘導体, modified $\beta$-lactam antibiotics, の合成が行なわれてきている。すでに興味ある数種の誘 導体が報告され，有機化学的にもまた構造一活性相関性 からもかなりの成果が得られている。

Azetidinone (46) ${ }^{30)}$ は Woodward, Heusler らによ る $\mathrm{Cp}-\mathrm{C}$ 全合成の重要な中間体であり， $\mathrm{S}$ 原子抢よび N原子に各種の置換基を導入することができる。したが 

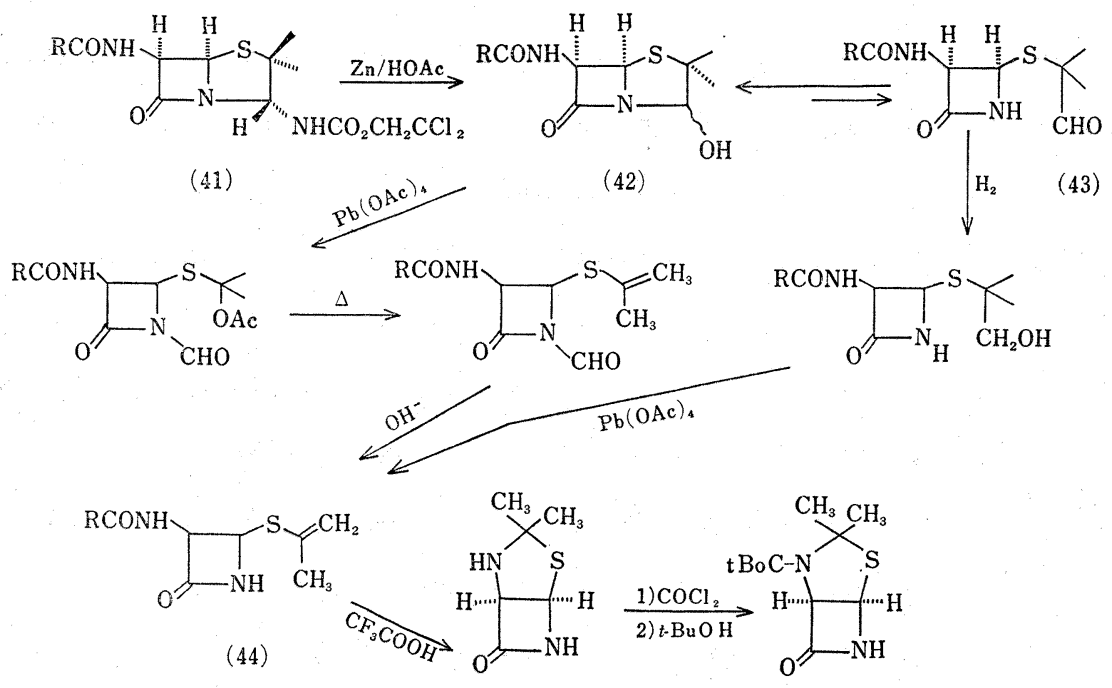

(45)

(46)

a) $\mathrm{R}=\mathrm{C}_{6} \mathrm{H}_{3} \mathrm{OCH}_{2}$; b) $\left.\mathrm{CCH}_{3}\right)_{3} \mathrm{O}$; c) $\mathrm{CCl}_{2} \mathrm{CH}_{2} \mathrm{O}$

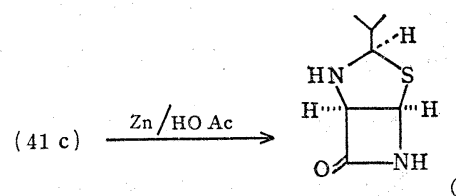

(18)

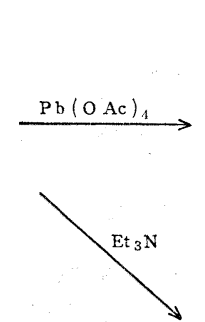

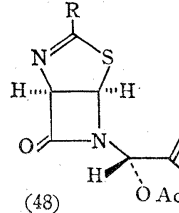

$(48)$
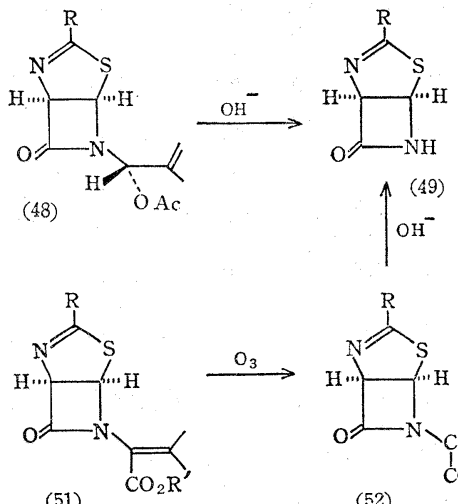

(51)

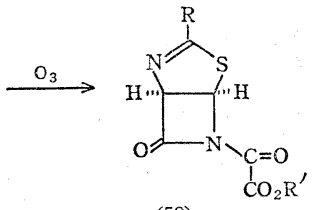

$(52)$

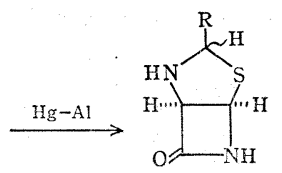

(50)

(47) 沬 (46) と全く同样に使用でき，また後者の方法注 前者と比較してかなり有利な方法である。

一方 Cooper ${ }^{35}$ ) らは（47）および関連化合物 (50) を 全く別途江合成した。先の Pc-oxide 転移反応莸活用す るところにその骨子がある。す なわち（18a）を塩基で処理し （51）とした後，塩化メチレン 中 $-78^{\circ}$ でオゾン酸化し高收率 で（52）を得た。この oxalyl 側鎖をメタノール中アルコラー トで処理除去して azetidinone （49）を得ることに成功した。 酸化は $\mathrm{OsO}_{4}{ }^{34)}$ あるいは過マン

a) $\mathrm{R}=\mathrm{C}_{6} \mathrm{H}_{5} \mathrm{OCH}_{2} ; \mathrm{R}^{1}$ $=\mathrm{CCl}_{3} \mathrm{CH}_{2}$

b) $\mathrm{R}=\mathrm{C}_{6} \mathrm{H}_{5} \mathrm{O}\left(\mathrm{CH}_{3}\right)_{2}$; $\mathrm{R}^{1}=\mathrm{H}$ ガン酸 ${ }^{34)} リ$ ガも行なわれてい るが，後者では值接 (49) が得 られる。(49) を $\mathrm{Al}-\mathrm{Hg}$ 還元 すれば azetidinone (50) ${ }^{35)}$ が得

って（46）ないしは相当する化合物を Pc より誘導でき るならび有利な中間体となり得る。

Heusler $^{31)}$ は次に示す如く (46) および関連する (47) の合成に成功した。すなわち Sheehan ら ${ }^{32)}$ の方法によ って得た（42）および (42) からそれぞれ記載の如く (44a) を合成した。同様に (42b) から (44b) を得て, こ 孔を三フッ化酢酸で処理すれば分子内閉環しazetidinone （45）が得られた。（45）を常法により（46）とし，こ こに Pc からの誘導が完成した。一方 dicarbamate (41c) $)^{33)}$ を $\mathrm{Zn}$-HOAc で還元的に保護基を除去して, られる。この一連の反応を(18b) に適用し, 先に Heusler によって合成された (47) を得ている。さらに Cooper ら ${ }^{36)}$ は別法による (49) の合成を報告している。(18)な いしはその誘導体を四酶酸鉛酸化して acetate (48) を 得て，次いで加水分解し側鎖を除去して（49）を得てい る。この反応も収率がよい。

以上の如く Pc より得られた（46）あるいは (47)を 用いて Woodword, Heusler らは数種の新しい誘導体を 合成したが，それらの中には活性の高いものもあって， 構造と活性との関連を考える上で興味ある知見が得られ 


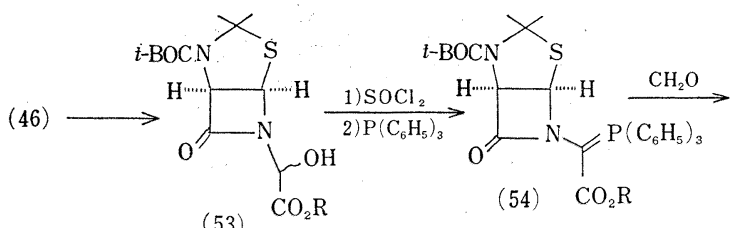

(53)

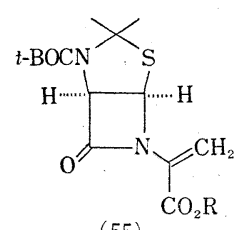

(55)<smiles>[R]C(=O)NC1C(=O)N2C(C(=O)O)CSS[C@H]12</smiles><smiles>[R2]C(=O)C(CSCC(=O)[Hg])N1C(=O)[C@H]2[C@H]1SC(C)(C)N2[R16]([H])([H])[H]</smiles>

(58)

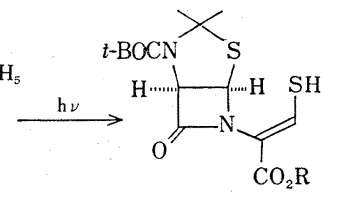

(59)

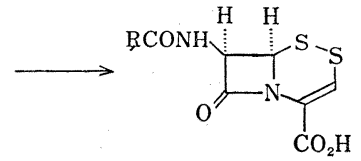

(60)

ている。(46) は glyoxalate と容易に縮合し adduct (53) が得られる。これを chloride とし, 次いで塩基 の存在下 $\left(\mathrm{C}_{6} \mathrm{H}_{5}\right)_{3} \mathrm{P}$ と反 応させて安定な phosphorane (51) を得た。(51) は 活性なアルデヒドと反応す るがケトンとは反応しな い。(51) のホルマリン付 加物（55）に硫化水素を付 加し mercaptan (56) を得 た。これを脱 $t$-Boc 化後, ヨウ度酸化して閉環し次い でアチル化して (57) を得 た。（57）は二種の 異性体 の混合物であるが，両異性 とも若干の抗菌力を示すと 報告している。当然のこと ながら（57）に二重結合を 導入した（60）は，活性が 増大すると考えられる。先 の（56）をアルキル化し，得られた（58）を脱 Boc 化後 ピリジンの存在下紫外線照射すれば（59）が得られる。 （59）を上記と同様に沃度酸化およびアチル化して（60） を得た。予期の如く（57）より強い活性を示すと報告し ているが，詳細は不明である。

さらに Woodward ${ }^{36)} ら は$ phosphorane (54) から, グラム陽性菌に強い活性を示す（62）の合成に成功し た。(54)に 《ーケトアルデヒドを縮合させれば cis およ び trans の混合物として（61）が得られる。この trans 体を三フッ化酶酸で処理閉環し，次いでアチル化して （62）を得た。(62）の中にはグラム陽性菌に対し Pc と

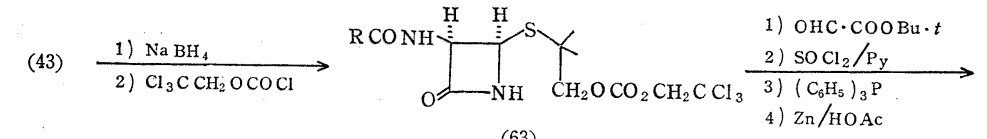

$\underset{\mathrm{DMSO} / \mathrm{Ac}_{2} \mathrm{O}}{\longrightarrow} \mathrm{RCONH}$
63<smiles>[R]C(=O)N[C@H]1C(=O)N2C(C(=O)O)=CCS[C@H]12</smiles>

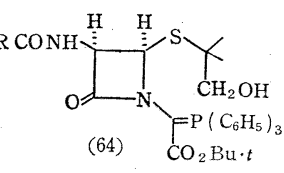


同程度の活性を示すものがあるが，in vivo 活性は低下 すると報告している。

Woodward ら ${ }^{37}$ は cephacillin と命名した (65) を合 成した。Cp との類似性から高い活性が期待されるが， その詳細は不明である。合成法は，上に述べた方法と基 本的には同一であり，(63）を経て phosphoran (64) と し次いで酸化し，閉環させて（65）を得ている。また同 様な方法によって, $(66)^{39}$ および (67 ${ }^{38}$ を合成してい るが，後者はほとんど活性を示さない模様である。

ところで Barton らも, 先に得たスルフェン酸捕捉体 (21)，(22）などの側鎖を除却し azetidinone 一誘導 ${ }^{40)}$, 新ためて置換基を導入し，新しい誘導体の合成 ${ }^{41)}$ を行な っているが，特に有効な化合物は得られていないようで ある。すなわち先の (21) から (68) とし，これにジア ゾメタンを作用させれば，反応注きわめて遅いが定量的 に付加し azine (69) が得られる。これを $t$ - BuOK ある いは Zn-HOAcで処理し，それぞれ azetidinone (70)
誘導することと成功した。後者の方法がより一般的であ り，この方法により (71) が合成されている。また (71) より（82）あるいは $(73)^{41}$ などの合成も報告してい る。 ところで, Wolf らの anhydro Pc (74) ${ }^{42)}$ の合成は, 最も古くから知られている $\mathrm{S}-\mathrm{C}_{1}$ 結合の閉裂方法であ る。(74) は $\mathrm{Pc}$ より安定であり $\mathrm{Cp}$ への転換など, 利 用されたが大きな発展にはない。最近 Wolf は (74) か ら Pcへの再閉環に成功 ${ }^{43}$ している。また下に示す如く

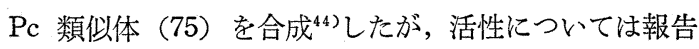
がない。

Kukolja ${ }^{45)}$ は S-C S $_{5}$ 結合の切断に始めて成功した。 (76)を1モルの塩素または $\mathrm{SO}_{2} \mathrm{Cl}_{2}$ で処理すれば（77）が 得られる。これはジオキサン中塩化スズで還元すること により（76）を再生する。また（77）にメルカプタンを 反応させ disulfide (78) とし, 三フッ化酢酸中加熱閉環 させて (79) および (80) を得た。これらはきわめて弱

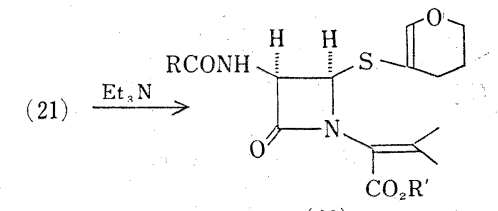

(68)

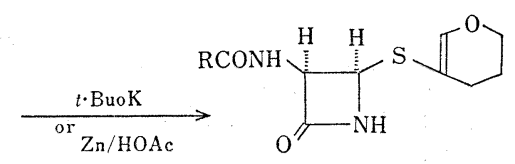

(70)

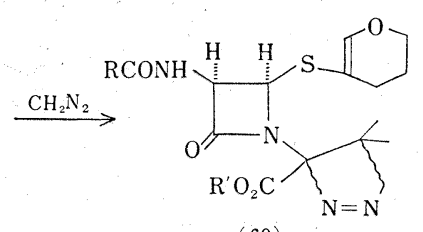

(69)

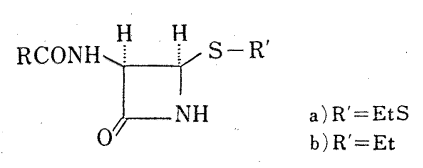

(71)

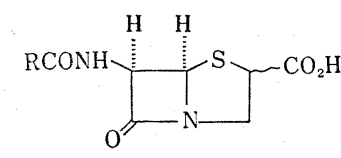

(72)<smiles>[R]C(=O)NC1C(=O)N(CC(=O)O)C1SCC</smiles>

(73)

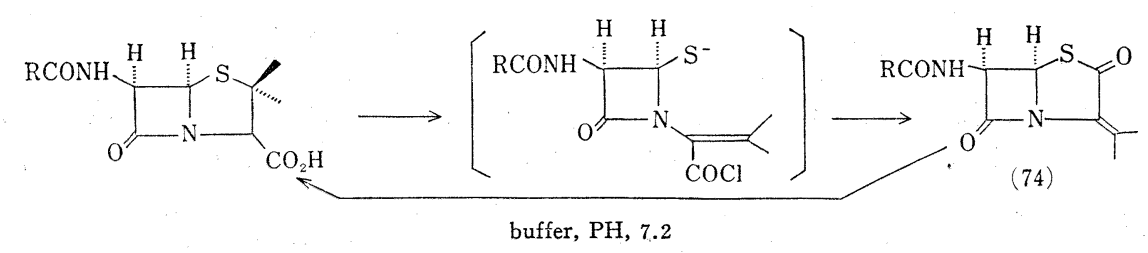

(74)<smiles>[R]OC(C)=C(C)N1C(=O)C([Z17])[C@H]1Cl</smiles>

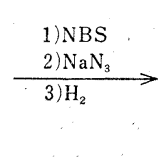<smiles>[R]OC(=O)N1C(=O)C(C(C)N)C1Cl</smiles><smiles>CCC1C(=O)N2C(C(=O)O)=C(C)CNC12</smiles>

(75) 
(76)<smiles>[R]C(=O)C1N2C(=O)C([Z17])[C@H]2SC1(C)C</smiles><smiles>[R]OC(C)([Si])C([R])([Si])N1C(=O)C([Z17])C1Cl</smiles>

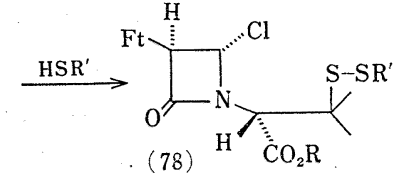

$(78)$

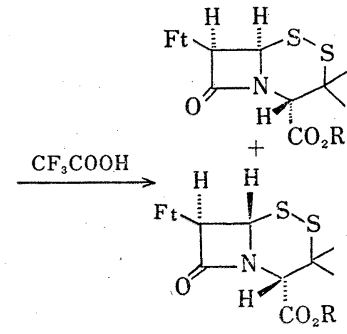

(80)
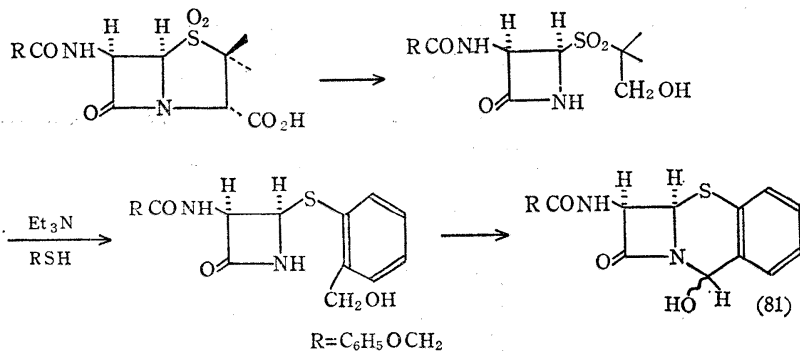

を $\mathrm{CuCl}_{2} \mathrm{HgCl}_{2}$ などで処理すればほとんど 定量的に (82), ( $\mathrm{Y}=\mathrm{Cl})$ が得られる。またメ夕 ノール中銀塩と処理すれば cepham (83), ( $\mathrm{Y}=$ $\left.\mathrm{OCH}_{3}\right)$ が, $\mathrm{AgBF}_{4}$ の存在下アニリンを作用 させれば cepham(83), $\left(\mathrm{Y}=\mathrm{NHC}_{6} \mathrm{H}_{5}\right)$ を, それ ぞれ $40 \%$ の收率で得られた。一方酶酸中酢 酸銀で処理すれば penam ( $82, \mathrm{Y}=\mathrm{oAc})$, cepham $(83, \mathrm{Y}=\mathrm{oAc})$ および cephem (40) を $8: 2: 3$ の割合で得られる。これらの事実か
い活性を示すに過ぎない。

最近 sheehan らは盛んに $\mathrm{S}^{-\mathrm{C}_{5}}$ 結合あるいは $\mathrm{N}-\mathrm{C}_{2}$ 結合の開裂により新しい化合物への誘導を試みている。

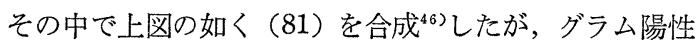
菌に対して強い活性を示すと報告している。カルボン酸 をもたないにも方かわらず活性を示すことは，興味ある 知見である。

以上のように, Pc から各種の誘遒体が合成されてい るが，いゔれも繁雜でありかなりの工程数を必要とす る。著者らも先に得た disulfide (34) および halomethyl （35）を用いて興味ある誘導体を簡単に，しかも高収率 で誘導することに成功している。

すでに述べたように（34）および（35）の反応からス ルフェン酸誘導体 (38) ないしは episulfonium ion (39) の生成が推定され, 求核試薬の導入に利用できると考え られる。以下のように全く新しい2 置換 $\mathrm{Pc}$ を合成する

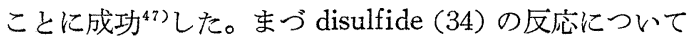
述べると，プソイド八ロゲンといわれる $(\mathrm{SCN})_{2}$ を作 用させれば，ハログンと同栐に（82）(Y=SCN) を $90 \%$ の収率で得た。一般に S-S 結合收比較的安定であるの で，求核試薬のみで切断することは困難と考えられる。 しかし, 重金属イオンの存在下求核試薬を作用 ${ }^{48}$ させる ことにより，置換基の導入に成功した。すなわち（34）
ら,スルフェン酸誘導体が中間に存在し得ると考え, 比較 的安定であるスルフェン酸アミドの単離を試みた。その 結果, anilide (84), $\left(\mathrm{Y}=\mathrm{NHC}_{6} \mathrm{H}_{5}\right)$ を $90 \%$ の収率で単離 することに成功した。これを $\mathrm{BF}_{3} \cdot \mathrm{OEt}_{2}$ で処理すれば， 先に得た (83), $\left(\mathrm{Y}=\mathrm{NHC}_{6} \mathrm{H}_{5}\right)$ が得られ中間体であること が確められた。この機構は下に示す如く, (34) から直接 に，または（84）を経て episulfonium ion (85) を形成 し，次いでそれぞれ生成物が得られるむのと考えてい る。anilide (84), $\left(\mathrm{Y}=\mathrm{NHC}_{6} \mathrm{H}_{5}\right)$ の捕捉に成功したが, 前 者の機構を否定するものではない。

ところで (84) の S-N 結合は S-S 結合よりも酸に 弱く, したがって適当な求核試薬の存在下ルイス酸を作 用させるならば，同様に（82）抢よび（83）の合成に利 用できると考えられる。事実 $(84),\left(\mathrm{Y}=\mathrm{C}_{6} \mathrm{H}_{5} \mathrm{NH}\right)$ に塩酸 を作用させれば (82), ( $\mathrm{Y}=\mathrm{Cl})$ を定量的に，またメタノー ル中 $\mathrm{BF}_{3}$ で処理すれび( 82$),\left(\mathrm{Y}=\mathrm{OCH}_{3}\right)$ および (83), $(\mathrm{Y}=$ $\left.\mathrm{OCH}_{3}\right)$ が 1:5 の割合で得られるなど，有用な中間体 でもある。上記の反応では，求核試薬によって（82）お よび（83）の生成比が異なるが，恐らく求核性の差によ るものと考えている。またこの反応で求核試薬が存在し なければ，(34）は cephem（40）に閉環するのみであ る。たとえば（34）をアセトニトリル中 $\mathrm{AgF}$ で処理す れば（40）が高収率で得られる。ここに得た化合物の 


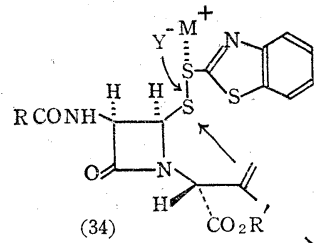

(34)
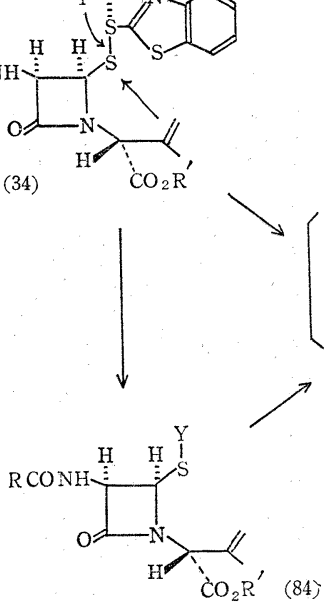

$\mathrm{R}=\mathrm{C}_{6} \mathrm{H}_{5} \mathrm{CH}_{2} ; \mathrm{C}_{6} \mathrm{H}_{5} \mathrm{OCH}_{2}$ $\mathrm{R}^{1}=\mathrm{CCl}_{3} \mathrm{CH}_{2} ; \mathrm{CH}_{3}$

(35)

(37)

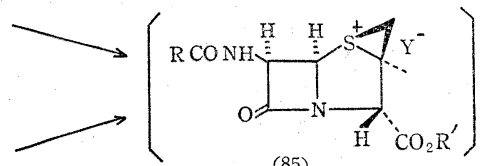

(85)

a) $\mathrm{Y}=\mathrm{SCN}$; b) $\mathrm{Y}=\mathrm{Cl}$;

c) $\mathrm{Y}=\mathrm{O}=\mathrm{COCH}_{6}$; d) $\mathrm{Y}=\mathrm{OCH}_{3}$;

g) $\mathrm{Y}=\mathrm{N}>\mathrm{S}$

(85)

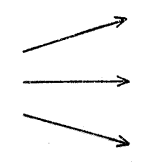

(82)

(83)

立体配位については後述する。

一方 haloide (35) および (37) む，同棣に（82）な いしは (83) の合成に利用 ${ }^{49}$ )できる。特にこれらは，S 原子の隣接基関によって反応性は増大している。( $35, \mathrm{~b})$ をアセトン中 $\mathrm{KSCN}$ または $\mathrm{NaN}_{3}$ を反応させれば， 前者からは penam(81)，( $\mathrm{Y}=\mathrm{CN})$ のみが，また後者から は（40）の副生を伴うが, $\operatorname{penam}(83),\left(\mathrm{Y}=\mathrm{N}_{3}\right)$ が，それ ぞれ收率よく得られた。また phosphate buffer (PH 6.0 ～7.0) 中チオール類,たとえば 2-mercaptobenzothiazole を作用させれば， disulfide $(34, \mathrm{a})$ および penam $(82, \mathrm{~g})$ がそれぞれ 40\% の收率で得られ，僅少の cepham (40) が副生する。他の異項環チオールによっても, 同様に相 当する化合物が得られる。

以上の結果から, episulfonium ion (85) の存在が容 易に推定される。したがって（35）および（37）から, （82）および（83）が同一の割合で生成すると期待され る。 $(35, \mathrm{~b})$ および $(37, \mathrm{~b})$ を同一条件の中で, $\mathrm{AgBF}_{4}$ 存在下メタノール，アニリンおよび酶酸中酢酸銀を作用 させたところ全く同一の割合で（82）および（83）を得 た。その結果は表 1 に示す通りであり，(85）を通る機 構が確認されたこと, また penam および cepham の相 互変換に成功したこととなる。最近 Kukolja ${ }^{27}$ も penam および cepham の相互変換について報告している。

これらの反応によって得た（82,a～g $)$ の立体配位は，
それから誘導した sulfoxide が，いずれも 5 位の水 素とメチル基との間で 13 〜 17\%の NOE が観察さ れること，および $(82, \mathrm{c})^{14)}$
(82)

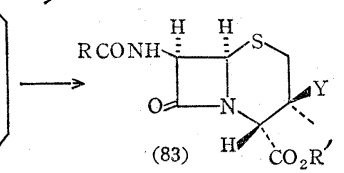
がすでに $\beta$ 配位であると 決定されている事実に基づ き、づれも $\beta$ 配位であ ると結論される。一方 cepham $(83 \mathrm{a} \sim \mathrm{g})$ では, 反応 機構の考察より $\beta$ 配位で あると推定した。以上のよ らに上記二種の反応によっ て, $\beta$ 体のみが立体選択的 に得られる。すでに Cooper ら ${ }^{24}$ ) 生成物の配位は episulfonium ion の生成の際に 決定されと述べているが，著者らの結果も，この説明に 一致する。すなわち, episulonium ion はスルフェン酸 誘導体の $\mathrm{S}$ 原子と分子内二重結合との $\mathrm{SN}_{2}$ 反応によっ て形成される。この際二種の geometry (A) および (B) が考えられ，脱離基が最も立体的な影響を受け易いとす れば， 7 位置換基の影響の少ない方向に脱離する。換言 すれば，(A) によって示されるごとく二重結合は $\beta$ 方 向より近今゙き，生成する episulfonium ion (85) および 生成物はいら゙れも $\beta$ 配位となると考えられよう。ここに 得た (82 a g) は, 全く新しい Pc 誘導体であり, 興 味ある抗菌活性を示すものが少なくない。この中には Pc-G に匹敵する誘導体も得られている。

以上のように, 分子求核置換反応について述べてきた が，分子間のみならず分子内置換反応 ${ }^{49}$ も起ることを認 めた。すなわち, (35,b) 塩基で処理し cephem (40) の環拡大反応を検討中, 使用する塩基によって茎少の副

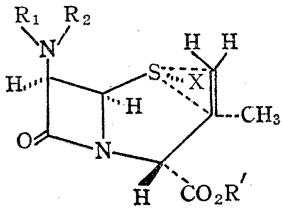

[A]

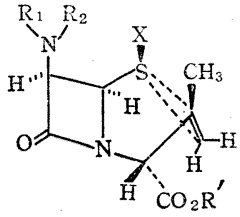

[B]
表 1

\begin{tabular}{c|c|c|c}
\hline $\mathrm{Y}$ & $(82)$ & $(83)$ & $(40)$ \\
\hline $\mathrm{NHC}_{6} \mathrm{H}_{5}$ & 6 & 1 & trace \\
$\mathrm{OCOCH}_{3}$ & 3 & 1 & $\prime \prime$ \\
$\mathrm{OCH}_{3}$ & 1 & 4 & $\prime \prime$ \\
\hline
\end{tabular}


(35)

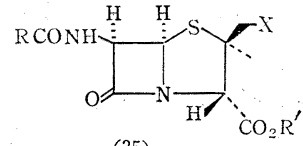

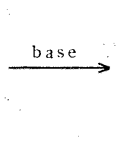

$\downarrow$ Peracid

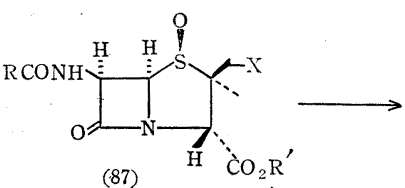

(87)<smiles>[R]C(=O)N[C@@H]1SC2(C)C[C@H]3[C@H](C2)N3C1=O</smiles>

(86) $\stackrel{\mathrm{C}_{2}}{\mathrm{R}^{\prime}}$

$\int_{\text {DMF }}^{\mathrm{PCl}}\{\mid$ Per acid

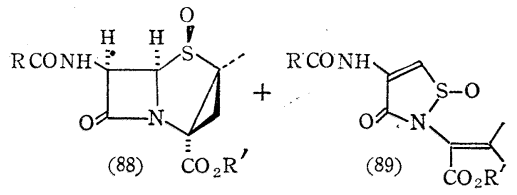

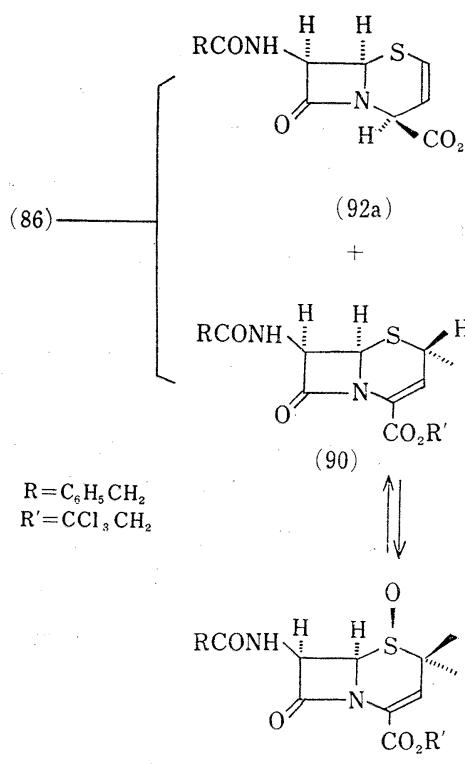

(93)

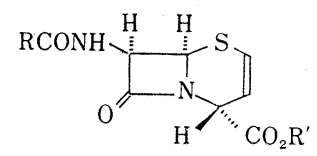

(92b)

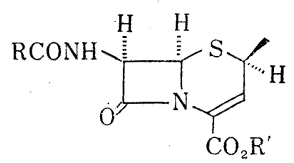

(91)
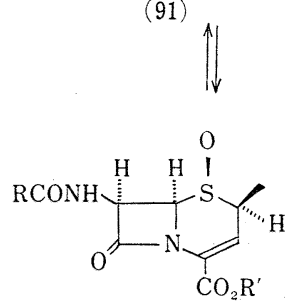

(94) $\beta$-ラクタム環と同一の方向であるの

で，かなりの歪がかかっているもの と思われる。Pc あるいは $\mathrm{Cp}$ と同 様に誘導体を合成したが，現在のと ころ特筆すべき誘導体は得られてい ない。

次いで著者らは，(86）の cyclopropane 環を開環し, 新たな誘導体 への展開を行ない，以下述べるよう なきわめて興味ある化合物を得る50) ことに成功した。

cyclopropane 環は反応性に富む が， $\beta$-ラクタム環に損障を与えるこ となく, 反応を行なうのはかなりむ ずかしいと考えられる。著者らはル イス酸による開環反応を検討し, 全 く新しい誘導体 (91)，(92）および （86）の合成に成功した。すなわち, （86）を塩化メチレン中, 塩化アルミ あるいは臭化アルミで処理すれば， 主生成物として (90) が得られ, 後 者の場合 (91) および (92) が副生 する。一方, $\mathrm{TiCl}_{4}$ では (92a)が主 生成物であって, 少量の（90）を副 生するに過ぎないなど，使用するル イス酸によって著しく影響されるこ とが判明した。種々検討の結 果, $\mathrm{AlBr}_{3}$ を用い，反応温度を規定する ことによりほとんど選択的に（90） を得ることができた。その収率は 80\% に達する。

これらの構造は，それぞれ単離確認しているが，(90) 生物の生成を認めた。その構造を検討した結果，分子内 閉環体 (86) であることが確認された。すでに述べたご とく, 塩基によって（40）が高収率で得られるため, （86）を選択的に得ることは困難であると考えられた。 しかし条件検討の結果, DMF 中低温で, DBUを使用す ることにより高収率で（86）を得ることに成功した。一 方 oxide（87） も塩基によって同様に閉環体（88）が高 収率で得られる。この場合は $\mathrm{S}$ 原子の関与がなく, 環拡 大の可能性はないが，6位水素が抜けて生成したと考元 られる（89）を副生する。(88) と（86）とは，酸化ある い法還元によって相互に変換され，同定確認された。

この (86) は分子内に cyclopropane 環を有する三環性 化合であり，いわば Pc と $\mathrm{Cp}$ との中間とも考えられる化 合物である。しかし cyclopropane 環は $\beta$ 配位であり,
および (91) の立体配位は NMR より以下のごとく決 定した。すなわち（90）では 2 位および7 位水素との間 に long range coupling $(\mathrm{J}=1 \mathrm{~Hz})^{51)}$ がみられるが，(91) では認められない。一方 oxide (94) では，2 位と 6 位 の水素は 1,3-diaxal の関係にあり, long range coupling $(\mathrm{J}=1.5 \mathrm{~Hz})^{52)}$ が認められる。これらの結果から,メチル 基の配位は，(90) では $\alpha$ ，また（91）では $\beta$ と考えら れる。さらに 2 位と 3 位水素との結合定数を比較すれ ば, (93) では $7 \mathrm{~Hz}$ ，また (94) では $2 \mathrm{~Hz}$ であり，(94) の 2 位水素が axial とすればその dihydroangle は $90^{\circ}$ に近く，また (93) では $0^{\circ}$ に近いと考えられる結果と 一致する。

一方（92a）㧍よび（92b）注立体異性体であるが，前 


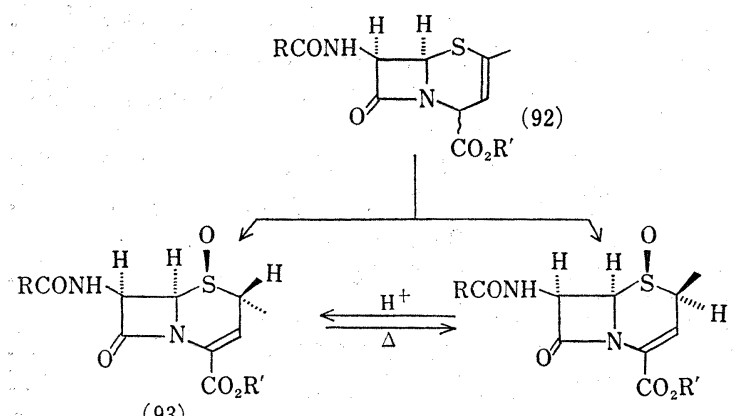

(93)

(94)

者では 7 位水素と 4 位水素との間に, long range coupling $(\mathrm{J}=1.5 \mathrm{~Hz})^{55)}$ が認められる事実より，4 位水素は (92a) では $\alpha に ＼mathrm{~ ま た ~(92 b) ~ て ゙ は ~} \beta$ に配位している 推定される。

（92a）および（92b）をそれぞれ過安息首酸で酸化 ${ }^{54}$ すれば（93）および（94）を前者からは $1.7: 1$ ，また 後者からは $1: 2$ の割合で得られた。両者は分離後, そ れぞれ(90) および (91) を酸化して，同定確認された。 また oxide (93) をDFM-ジオキサン中ジメチルアミン 塩酸塩と加熱すれば，(93）拉よび (94) の平衡混合物が 得られる。

（90）は下に示すごとく，常法により amine（95）に 導き，再びアチル化すれば各種アチル誘導体が合成され る。

ここに得られた（90）および (91) 誘導体の抗菌活性 は，7位アチル基の如何にかかわらず以下に示すような 関係が成立する。特に天然由来の (40) 誘導体よりグラ

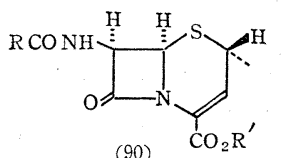

(90)

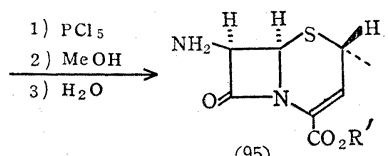

(95)
么陽性および陰性菌に対し高い活性を示す事実は興味あ る知見といえよう。今回は触れなかったが，(96 $)^{52) あ る ~}$ いは $(97)^{53)}$ など近縁な化合物が，すでに合成されグラ 么陽性菌に対し，強い活性を示寸と報告されている。ま た先に述べた $(60,(62),(65),(66)$ および (67) の活性 と, 著者らの得た結果を考え併せると, わずかなメチル 基の位置の違い，あるいは $\alpha$ または $\beta$ 配位玑よって， 著しく活性に 影響をおよぼしている事実は構造-活性相 関を考える上できわめて興味ある知見である。

\section{IV. むす び}

$\mathrm{Pc}$ からデスアセトキシ $\mathrm{p}$ 狟換，および新しい誘 導体の合成について，その概要を紹介した。本分野の研 究はぼう大かつ多岐にわたり，今後ますます発展するも のと考えている。これは $\beta$-ラクタム抗生物質の実用上 の価值にもよるが，同時に化学的な興味によるところも 大きいといえよう。この拙文から，その間の実情をくみ とって戴けたら幸甚である。また依頼を受けた主題にそ ぐわず，著者の興味に片寄った感があるが，ご寛容戴け れば幸いである。最後にご鞭䩼を頂いた当中央研究所長 中野 浩博士，また協同研究者の寺地 勉, 斎藤能久, 橋本真志，中口 修，奥，照夫の諸氏に厚く謝意を表す るしだいである。

(昭和 49 年 8 月 5 日受理)

\section{文献}

1) G.G. Newton, E.P. Abraham, Nature 175548 (1955)

2) E.P. Abraham, G.G. Newton, Biochem. J. 79 377 (1961); D.C. Hodgkin, E.N. Maslen, Biochem. J. 79393 (1961)

3) R.R. Chauvette, P.A. Pennington, C.W. Ryan, R.D.G. Cooper, F.L. Jose, I.G. Wright, E.M. van Heyningen, G.W. Huffman, J. Org. Chem. 361259 (1971)

4) R. Nakaranjan, L.D. Boeck, M. Gorman, R.L. Hamill, C. E. Higgens, M. M. Hoehn, W. M. Stark, J.G. Whitney, J. Amer. Chem. Soc. 93 2308 (1971) ; C.E. Higgens, R.E. Kastner, Int. J. Syst. Bacteriol. 21326 (1971); G. AlbersSchönberg, B.H. Arison, J.L. Smith, Tetrahedron Lett. 1972 2911；藤沢，特開昭 49-30593

5) E.P. Abraham, Quart. Rev. Chem. Soc. 21231 (1967) ; F.P.Doyle, J.H.C. Nayler, in "Advanced in DrugResearch"1(1964); E.M. van Heyningen, in "Advonced in Drug Research" 4 (1967); J.P. Hon, J.W. Poole, J. Pharm. Siences. 60 503 (1971); J.L. Luche, G. Balavoine, Bull. Chem. France 1971 2733; R.B. Morin, B.G. Jackson, F. Chem. org. 28343 (1970); E.H. Flynn, "Cephalosporins and Penicillins" Academic Press (1972) 
6) R.B. Morin, B.G. Jackson, R.A. Mueller, E.R. Lavagnino, W.B. Scanlon, S.L. Andrews, J. Amer. Chem. Soc. 85 1896(1963); 91 1401(1969)

7) C.W. Rynan, R.L. Simon, E.M. nan Heyningen, J. Med. Chem. 12310 (1969)

8）藤沢，特関昭，49-25193；C.E. Higgens, R.L. Hamill, T.H. Sands, M.M. Hoehn, N.E. Davis, R, Nagarajan, L.D. Boeck, J. Antibiotics 27 298 (1974)

9) Lilly, 特開昭 47-27-2507, ef. ref. (6)

10) Glaxo, 特開昭 47-10395

11) R.D.G. Cooper, J. Amer. Chem. Soc. 925010 (1970); R.D.G. Cooper, F.L. Jose, J. Amer. Chem. Soc. 922575 (1970)

12) D.H.R. Barton, F. Comes, D.G.T. Greig, G. Leucent, P.G. Sammes, W. G. E. Underwood, Chem. Commun. 19701059

13) R.D.G. Cooper, P.V. Demarco, D.O. Spry, J. Amer. Chem. Soc. 91 1528(1969) D.O. Spry, J. Amer. Chem. Soc. 925006 (1970)

14) D.H.R. Barton, D.G.T. Greig, G. Lucent, P.G. Sammes, H.V. Taylor, C.M. Cooper, G. Hewitt, W.G.E. Underwood, Chem. Commun. 19701683

15) D.O. Spry, J. Amer. Chem. Soc. 92 5006(1970)

16) L.D. Hatfiend, J. Fisher, F.L. Jose, R.D.G. Cooper, Tetrahedron Lett. 19704897

17) D.H.R. Barton, P.G. Sammes, M.V. Tayler, C.M. Cooper, G. Hewits, B.E. Iooker, W.G.E. Underwood, Chem. Commun. 19711137

18) D.H.R. Barton, D.G.T. Greig, P.G. Sammes, M.V. Taylor, Chem. Commun. 1971845

19) T. Kamiya, T. Teraji, Y. Saito, M. Hashimoto, O, Nakaguchi, T. Oku, Tetrahedron Lett. 1973 3001

20) T.S. Chou, J.R. Burgtorf, A.L. Ellis, S.R. Lammert, S,P. Kukolja; J. Amer. Chem. Soc. 96 1609 (1974)

21) T.S. Chou, Tetrahedron Lett. 1974725

22) G.E. Gutowski, B.J. Foster, C.J. Damiels, L.D. Hatfield, T.W. Fisher, Tetrahedron Lett. 1971 3433

23) S. Kukolja, S.R. Lammert, Angerv. Chem. Int. Ed. Engl. 1267 (1973)

24) R.D.G. Cooper, L.D. Hatfield, D.O. Spry, Account. Chem. Res. 632 (1973)

25) R.D.G. Cooper, J. Amer. Chem. Soc. 941018 (1972)

26) S. Terao, T. Matsuo, S. Tsushima, N. Matsumoto, T. Miyawaki, M. Miyamoto, Chem. Commun. 19721304

26) M. Numata, Y. Imashiro, I. Minamida, M. Yokoyama, Tetrahedron Lett. 19725097

27) S. Kukolja, S.R. Lammert, J. Amer. Chem. Soc. 947169 (1972)

28）塩野義，特開昭，49-24995

29）明治製菓，特開昭，48-103596
30) R.B. Woodward, K. Heusler, T. Gostelli, P. Naegeli, W. Oppolzer, R. Ramage, S. Ranganathan, H. Vorbrüggen, J. Amer. Chem. Soc. 88 852 (1966)

31) K. Heusler, Helv. Chim. Acta 55388 (1972)

32) J.C. Sheehan, K.G. Brandt, J, Amer. Chem. Soc. 875468 (1965)

33) B. Fechtig, H. Bickel, H. Heusler, Helv. Chim. Acta 55417 (1972)

34) E.G. Brain, A.J. Eglington, J.H.C. Nayler, M.J. Peason, R. Southgate, Chem. Commun. 1972229

35) R.D.G. Cooper, F.L. Jose, J. Amer. Chem. Soc. 941921 (1972)

36) R.B. Woodward, I. Ernest, K. Barri, R. Friary, F. Haviv, R. Paioni, K. Syhora, Unpublished results

37) R. Scartazzini, H. Pefer, H. Bickel, K. Heusler, R.B. Woodward, Helv. Chim. Acta 55408 (1972)

38) R. Scartazzni, J. Gosteli, Bickel, R.B. Woodward., Helv. Chim. Acta 552567 (1972)

39) R. Seartazzni, H. Bickel, Helv. Chim. Acta 55423 (1972)

40) D.H.R. Barton, D.G.T. Greig, P.G. Sammes, M.V. Taylor, Chem. Commun. 1971845

41) D.H.R. Barton, J. Chem. Soc. Perkin. Trans. I 1973 1187; Glaxo, 特開 昭 47-9025

42) S. Wolfe, J.C. Godfrey, C.T. Ifoldrege, Y.G. Perron, Canad. J. Chem. 462549 (1968)

43) S. Wolfe, R.U. Bassett, S.M. Caldwell, F.I. Warson, J. Amer. Chem. Soc. 917205 (1969)

44) S. Wolfe, J.B. Ducep, G. Kannengiesser, S.W. Lee, Can. J. Chem. 502902 (1972)

45) S. Knkolja, P.V. Demarco, U.D. Jones, O.M. Chaney, J.W. Paschal, J. Amer. Chem. Soc. 947590 (1972)

46) J.C. Sheehan, H.C. Dalzell, J.M. Greenwood, D.R. Ponzi, J. Org. Chem. 39277 (1974)

47) 紙谷, 寺地, 摘本, 中日, 奥 日本薬学会, 第94 年会, 講演要, p.67

48) M.D. Beutly, I.B. Duglass, J.A. Lacadie, D.C. Weaver, F.A. Davis, S.J. Eitelman, Chem. Commun. 19711625

49) 紙谷, 寺地, 橋本, 中口, 奥 日本薬学会第 94 年 会, 講演要旨 p.68

50）紙谷，寺地，橋本，中口，奥，未発表

51) R.D.G. Cooper, P.V. Demarco, C.F. Murphy, L.A. Spangle, J. Chem. Soc. 1970340

52) I.G. Wright, C.W. Ashbroock, T. Goodson, G.V. Kaiser, E.M. Van Heyningen, J. Med. Chem. 14420 (1971)

53) G.V. Kaiser, C.W. Ashbrook, T. Goodson, I.G. Wright, E.M. Van Heyningen, J. Med. Chem. 14426 (1971)

54) G.V. Kaiser, J. Org. Chem. 352430 (1970)

55) D.O. Spry, Tetrahedron Lett. 1973165 